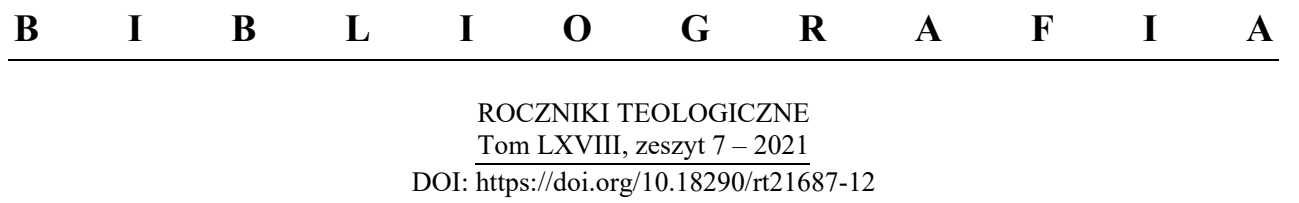

PIOTR KOPIEC

\title{
BIBLIOGRAFIA PRACOWNIKÓW SEKCJI EKUMENIZMU KUL W 2020 ROKU
}

\section{KS. PROF. DR HAB. MAREK JAGODZIŃSKI}

\section{MONOGRAFIE NAUKOWE}

- Zarys mariologii komunijnej. „Teologia w Dialogu”, t. 19. Lublin: Wydawnictwo KUL, 2019. ISBN 978-83-8061-838-1 ss. 214.

- Eschatologia w perspektywie komunii. „Teologia w Dialogu”, t. 20. Lublin: Wydawnictwo KUL, 2020. ISBN 978-83-8061-839-8 ss. 190.

\section{ROZDZIAŁY W MONOGRAFIACH WIELOAUTORSKICH}

- „Pneumatologiczny wymiar Eucharystii jako sakramentu komunii” W: Człowiek droga Kościoła. Tradycja i wspótczesność, red. Piotr Turzyński, Wojciech Wojtyła, 85-97. Radom: Łukasiewicz - Instytut Technologii Eksploatacji, 2020.

\section{ARTYKUŁY NAUKOWE}

- „Komunijne oblicze śmierci człowieka”. Studia Diecezji Radomskiej 11(2019): 263-278.

- „Personalistyczno-komunijne wymiary kolegialności - synodalności w Kościele”. Studia Teologii Dogmatycznej 5(2019) (Kolegialność w Kościele katolickim): 41-54.

Dr hab. PIOTR KopIEC, prof. KUL - Katolicki Uniwersytet Lubelski Jana Pawła II, Wydział Teologii, Instytut Nauk Teologicznych, Sekcja Ekumenizmu, Katedra Teologii Protestanckiej; adres do korespondencji: e-mail: petrko@kul.pl; ORCID: https://orcid.org/0000-0002-0581-0737. 
- „Communional Aspects of the Doctrine of the Holy Spirit According to John D. Zizioulas”. Teologia w Polsce 14(2020), 1: 31-45.

- „Komunijna mistyka eklezjalna według Johna D. Zizioulasa”. Roczniki Teologiczne 67 (2020), 7: 5-18.

\section{RECENZJE}

- Rec.: „Konsumpcjonizm na skrzyżowaniu socjologii i teologii”. [Piotr Kopiec, Konsumpcjonizm. Perspektywa protestanckiej koncepcji człowieka i społeczeństwa. Lublin: Wydawnictwo KUL, 2016, ss. 338. Roczniki Teologiczne 64(2017), 7: 191-196. ISBN: 978-83-8061-204-4].

- Rec.: Wojciech Wojtyła. Transcendencja i uczestnictwo. Wprowadzenie do myśli filozoficznej Jana Pawła II. Radom, 2017, ss. 142.] Radomskie Studia Humanistyczne 4(2017): 207-209. ISSN: 2300-0597.

- Rec.: Alterglobalizacja a Światowa Rada Kościołów. Cykl monografii na temat ekumenicznej interpretacji procesów globalizacyjnych w działalności Światowej Rady Kościołów. Roczniki Teologiczne 65(2018), 7: 179-182.

\section{WSPÓŁREDAKCJA PUBLIKACJI ZBIOROWYCH}

- Czynić diecezję domem i szkoła komunii. II Synod Diecezji Radomskiej, red. Piotr Turzyński, Sławomir Czajka, Marek Jagodziński, Stanisław Łabendowicz. Radom: Wydawnictwo Diecezji Radomskiej AVE, 2020, ss. 632.

\section{TŁUMACZENIA}

- [A. Štrukelj, Święty papież Jan Pawet II i kardynat Hans Urs von Balthasar (Heiliger Papst Johannes Paul II. und Hans Urs Kardinal von Balthasar], Międzynarodowy Przeglad Teologiczny Communio 2 (2020): 157-184.

\section{KS. PROF. DR HAB. PRZEMYSLAW KANTYKA}

\section{MONOGRAFIE NAUKOWE}

- Ekologia w teologiczno-społecznej refleksji ekumenicznej. Wybrane ujęcia [Ecology in Theological and Social Ecumenical Reflection. Selected Approaches], seria „Ekumeniczna myśl społeczna” t. 2 [series: “Ecumenical Social Thought", vol. 2 (ISBN seria: 978-83-7306-901-5)]. Lublin: Towarzystwo Naukowe KUL, 2020, ss. 134. ISBN 978-83-7306-896-4. 
- [wraz z Piotrem Kopcem, Marcinem Składanowskim] Ecumenical Social Thought An Outline, seria „Ekumeniczna myśl społeczna” t. 4. Lublin: Towarzystwo Naukowe KUL, 2020, s. 65-108. ISBN: 978-83-7306-898-8.

- [wraz z Piotrem Kopcem, Marcinem Składanowskim] Экуменическая общественная мысль. Очерк, seria „Ekumeniczna myśl społeczna” t. 5. Lublin: Towarzystwo Naukowe KUL, 2020, s. 75-122.

\section{ARTYKUŁY NAUKOWE}

- „Troska o stworzenie a «sprawiedliwość klimatyczna»”. Przeglad Uniwersytecki 1(183) styczeń-luty (2020): 32-33.

- „An Application of Category of Fraternity to the Grassroots Ecumenism on the Basis of Pope Francis' Encyclical Letter Fratelli tutti". Studia Oecumenica 20(2020): 7-16. ISSN: 1643-2762. DOI: 10.25167/so.3054.

\section{ARTYKUŁY POPULARNONAUKOWE}

- „Teolog paschalnej nadziei”. Przeglad Uniwersytecki 4(186) lipiec-sierpień (2020): 48-49.

\section{RECENZJE}

- „Opinia w postępowaniu o nadanie tytułu doktora honoris causa Katolickiego Uniwersytetu Lubelskiego Jana Pawła II Jego Eminencji Kurtowi Kardynałowi Kochowi". W: Kardynat Kurt Koch - Doktor honoris causa Katolickiego Uniwersytetu Lubelskiego Jana Pawta II, Lublin: KUL, 2020, s. 11-24; Gutachen in Verfahren zur Verleihung der Ehrendoktorwürde der Katholischen Universität Lublin Johannes Paul II. an Seine Eminenz Kurt Kardinal Koch, w: Kardynat Kurt Koch - Doktor honoris causa ..., s. 63-77.

\section{SPRAWOZDANIA}

- „Działalność naukowa Instytutu Ekumenicznego KUL w 2019 roku”. Roczniki Teologiczne 67(2020), 7: 201-215. DOI: https://dx.doi.org/10.18290/rt20677-17. 


\section{DR HAB. PIOTR KOPIEC, PROF. KUL}

\section{MONOGRAFIE NAUKOWE}

- Spoleczeństwo w teologicznej refleksji organizacji ekumenicznych. Panorama ujęć. Lublin: Towarzystwo Naukowe KUL, 2019, ss. 288. ISBN: 978-83-7306895-7.

- [wraz z Przemysławem Kantyką, Marcinem Składanowskim] Ecumenical Social Thought An Outline, seria „Ekumeniczna myśl społeczna” t. 4. Lublin: Towarzystwo Naukowe KUL, 2020, s. 15-66. ISBN: 978-83-7306-898-8.

- [wraz z Przemysławem Kantyką, Marcinem Składanowskim] Экуменическая общественная мысль. Очерк, seria „Ekumeniczna myśl społeczna” t. 5. Lublin: Towarzystwo Naukowe KUL, 2020, s. 5-74.

\section{ARTYKUŁY NAUKOWE}

- „Consumer society: Its definitions and its Christian criticism”. HTS Teologiese Studies/Theological Studies 3(76)2020: 8-15. DOI: https://doi.org/10.4102/ hts.v76i3.5910.

- „Teologiczne impulsy kulturowej i społecznej emancypacji Dalitów”. Przeglad Religioznawczy 2(276)2020: 97-112.

- „The Prosperity Gospel: A Distortion of the Fundamental Evangelical Tenets”. Studia Oecumenica 20(2020): 229-243.

- „Ecumenical Reading of Thomas Aquinas: The Idea of Participation as the Chance for the Interconfessional Theological Dialogue". Parrésia 13-14 (2019-2020): 337-343.

- „Teologiczny ruch Radykalnej Ortodoksji o protestantyzmie i scholastyce. Wprowadzenie w refleksje”. Nurt SVD 148(2)2020: 213-229.

- „Teologicznie o krytyce kapitalizmu: Ujęcie Johna Milbanka i ruchu Radykalnej Ortodoksji”. Teologia i Człowiek 52(4)2020.

\section{RECENZJE}

- Rec.: „Nieznana Rosja”. [Marcin Składanowski, Cywilizacja rosyjska. Studia $z$ historiozofii $i$ antropologii Aleksandra G. Dugina]. Roczniki Teologiczne 67(2020), 7: 177-179.

- Rec.: „Egzystencjalne spojrzenie na eschatologię”. [Marek Jagodziński, Eschatologia dzisiaj]. Roczniki Teologiczne 67(2020), 7: 179-181. 


\section{SPRAWOZDANIA}

- „Międzynarodowa Konferencja Naukowa «When We Look at Christ We See the World as It Is: Ecumenical Social Thought» («Kiedy patrzymy na Chrystusa, widzimy świat takim, jaki jest: Ekumeniczna myśl społeczna»), Katolicki Uniwersytet Lubelski Jana Pawła II, 4-5 marca 2019 roku”. Roczniki Teologiczne 67(2020), 7: 181-185.

- „Ekumenizm o sprawiedliwym społeczeństwie. Sprawozdanie merytoryczne z realizacji projektu Ekumeniczna nauka społeczna. Systematyka politycznych i społecznych aplikacji dialogów ekumenicznych". Roczniki Teologiczne 67(2020), 7: 189-199.

- „Bibliografia pracowników Instytutu Ekumenicznego/Sekcji Ekumenizmu Instytutu Nauk Teologicznych KUL w 2019 roku". Roczniki Teologiczne 67(2020), 7: 217-220.

\section{PROF. DR HAB. KRZYSZTOF LEŚNIEWSKI}

\section{ARTYKUŁY NAUKOWE}

- „Nowa prawna definicja śmierci w Polsce jako problem filozoficzno-teologiczny". Rocznik Teologiczny ChAT 62(2020), 4: 1281-1308.

- „Ekskluzywizm soteriologiczny w Kościele prawosławnym?”. Przegląd Religioznawczy 4(278)2020: 105-116.

\section{ROZDZIAŁY W MONOGRAFIACH WIELOAUTORSKICH}

- „Matka Boża w duchowości monastycznej i w codziennej pobożności prawosławnych chrześcijan". W: Kościót i Maryja, red. A.A. Napiórkowski. Kraków: Uniwersytet Papieski Jana Pawła II, 2020, s. 91-107.

\section{RECENZJA WYDAWNICZA}

- Recenzja wydawnicza monografii: abp. prof. dr. hab. Jerzy Pańkowski. Misterium metanoi i spowiedzi. Warszawa: Wydawnictwo Naukowe ChAT, 2020, ss. 355 . 


\section{KS. DR HAB. SLAWOMIR PAWLOWSKI , PROF. KUL}

\section{ARTYKUŁY NAUKOWE}

- „Ks. James Haldane Stewart: Wskazówki dla ogólnego zjednoczenia chrześcijan w modlitwie o wylanie Ducha Świętego (1820). Okoliczności powstania, tekst i przesłanie". Studia Oecumenica 20(2020): 245-261. DOI: 10.25167/ so.2517.

- „Ekumeniczne vademecum dla biskupów. Komentarz teologiczny”. Studia Oecumenica 20(2020): 437-452. DOI: 10.25167/so.3096.

\section{WSPÓŁREDAKCJA PUBLIKACJI ZBIOROWEJ}

- Życzliwymi bądźmy (por. Dz 28,2). Materiaty na Tydzień Modlitw o Jedność Chrześcijan 18-25 stycznia i caly rok 2020, red. Andrzej Gontarek, Sławomir Pawłowski, Edward Puślecki Doroteusz Sawicki, Kalina Wojciechowska. Warszawa, 2019.

\section{RECENZJA WYDAWNICZA}

- Recenzja wydawnicza: Ulryk Zwingli - teolog, humanista, reformator, red. Rafał Marcin Leszczyński, Ewa Jóźwiak. Warszawa: Wydawnictwo Naukowe ChAT, 2020, ss. 176.

\section{KS. DR HAB. TOMASZ SIEMIENIEC}

\section{ARTYKUŁY NAUKOWE}

- „«On to dla nas grzechem uczynił Tego, który nie znał grzechu» (2 Kor 5,21): Rozumienie Pawłowej wypowiedzi w historii egzegezy". Roczniki Teologiczne 67(2020), 7: 59-83.

- „Obietnice Ducha dla «martwych» w świetle Ap 14,13”. Verbum Vitae 37(2020): 129-143. 